Open Access

\title{
Three paradoxes in the approach to educational technology in the education studies of the Spanish universities
}

\author{
Joan Ferrés, Maria-Jose Masanet ${ }^{*}$ (i) and Julio-César Mateus
}

\author{
*Correspondence: mjose.masanet@ \\ upf.edu \\ MEDIUM Research Group, \\ Communication Department, \\ Universitat Pompeu Fabra, C/ Roc \\ Boronat, 138, 08018 Barcelona, \\ Spain
}

\begin{abstract}
The education studies of the Spanish universities are not alien to technological innovations, but their approach to them tends to be basically instrumental. Neuroscience's contributions about the functioning of the minds that interact with these technologies give new perspectives to the academic world; perspectives that are necessary for optimizing teaching-learning processes. This article analyses the recent scientific production on ICT and innovation in Spanish higher education, as well as the Spanish university teaching guides of education degree subjects about technologies. This critical analysis is organized around three paradoxes related to information, rationality and critical sense. Comparing the analysis results with the discoveries of neuroscience during the last decades reveals limits and contradictions in those areas that tend to be considered strongest in the technology-education relationship. We draw conclusions for revising the parameters for the approach to ICT in university education.
\end{abstract}

Keywords: ICT, Innovation, Higher education, Neuroscience, Educational technology, Spain, Media education, Storytelling, Entertainment, Emotions

\section{Introduction}

The objective of this article is to discuss from a critical perspective the instrumental approach that prevails in the academic field of educational technology in Spanish universities. The critical analysis is based on neuroscience findings on the functioning of the minds that interact with technologies.

The definition of educational technology - or edtech - is ambiguous, but there is a consensus that it constitutes a field of study related to the use of technology to improve the quality of learning (AECT Definition and Terminology Committee, 2008). Academic attention generally focuses on use and appropriation, omitting more complex interactions between the users' minds and the technologies, especially in relation to emotions and tastes. In this article we focus on the face-to-face or blended educational process, excluding the virtual, in Spanish higher education. Although the real impacts on learning are still questionable, the market for educational technologies continues to grow. Most universities around the world allocate large budgets to purchasing and maintaining technology and the virtualization of their services and management processes. Several reports evidence the increasing trends towards mobile-

(c) The Author(s). 2018 Open Access This article is distributed under the terms of the Creative Commons Attribution 4.0 International License (http://creativecommons.org/licenses/by/4.0/), which permits unrestricted use, distribution, and reproduction in any medium, provided you give appropriate credit to the original author(s) and the source, provide a link to the Creative Commons license, and indicate if changes were made. 
learning, cloud-computing, and the Internet of Things (IoT), as well as the use of new and more powerful mobile devices in the classroom (Adams Becker et al., 2017).

In Spain, according to the latest report by the ICT Sectoral Commission of the Conference of Deans of Spanish Universities (CRUE) access to technologies is a reality: virtual teaching, software license management for teaching and support for computer classrooms for teaching are implemented in a practical way in all universities, automated management in universities is already fully consolidated, and more than $80 \%$ of classrooms throughout the country have an Internet connection and multimedia projector (Gómez, 2016).

Faced with the unstoppable technologizing of higher education, the limited effects on the educational process are explained away by the lack of digital skills or institutional policies of the universities themselves: lack of incentives and time for teachers, as well as a very high learning curve (Sutton \& DeSantis, 2016). There is also sufficient evidence of the importance of intrinsic factors such as the teachers' subjectivity in the process of integrating technology in the classroom. In this sense, the teachers' beliefs, conceptions and approaches to the use of technologies are decisive for the success of this process (Englund, Olofsson, \& Price, 2016).

In this scenario, terms such as innovation or disruption abound in teaching plans and are discursively associated with the use of technologies without a clear explanation of how they relate or what role they play in these processes: "Many universities recognise the need to innovate, but there is no decisive leadership to tackle the actions of change that innovation requires" (Casas \& Stojanovic, 2013: 249). As Sevillano-García and Vázquez-Cano (2015) warn in a study on mobile devices in Spanish universities, "viewing each technological breakthrough as the quintessence of educational innovation is a mistake; other variables must also be considered, such as existing context and culture, educational practices and relations, and the way those involved conceive of teaching-learning processes" (107).

A recent study in the education studies of the Spanish universities concluded that teachers perceive that digital devices can be useful and functional from a didactic perspective. For instance, when they are used to conduct videoconferences, to manage ubiquitously chats and academic forums related to the subjects, or to encourage the participation of students in academic life. The creation and visualization of videos is a didactic activity that mobile digital devices favor in the current mobile and ubiquitous context of Higher Education (Vázquez-Cano, 2015). However, this instrumental dimension is not enough to transform traditional education the way ed-tech is capable of, by expanding this instrumental approach.

In short, despite the motivating power of technologies, the lack of clarity in the ICT strategies and projects in higher education is an urgent challenge that must be addressed. This article draws attention to the prevalence of the instrumental approach to technologies and the absence of other essential dimensions linked to neuroscientific findings.

We speak of paradoxes because, comparing the academic approach to technologies in Spanish universities with neuroscience findings on the human mind, we discover that behind the most powerful and relevant academic concepts (information society, cognition and critical thinking) hide shortcomings that prevent more effective and more integrative education (entertainment and storytelling, emotion and critical attitude). In this context, we propose the following specific objectives: 
SO1: Determine the attention given to the areas of information and entertainment in the Spanish university approach to educational technology.

SO2: Determine the attention given to the cognitive and emotional areas in the Spanish university approach to educational technology.

SO3: Analyse whether critical sense is related to knowledge or attitude in the Spanish university approach to educational technology.

With this we aim explore which areas are more present in the selected documents, whether there is a significant disproportion between them and whether some are invisible or are practically not considered at all, thus demonstrating the seriousness of these deficiencies.

To organise this article, we propose three paradoxes related to informational, cognitive and critical areas, discussed based on the available literature.

The dichotomies between information and entertainment, between motives and emotions and between criticism and critical attitude are not presented for the defense of one option against the other, but to emphasize the need for the integration of complementary poles and, therefore, to draw attention to the need to cover the gaps to optimize the teachinglearning processes.

\section{Contextualising the three paradoxes}

\section{The inadequacy of the informational}

To start, the discoveries of neuroscience on the functioning of the human brain reveal that stories are much more effective than explicit information for motivating people (Keysers, 2011; Ramachandran, 2011; Salmon, 2008). This is assumed and applied by professionals of persuasive communication in all fields, from advertising and marketing to politics and business communication. Increasingly more people focus their communication strategies on the potential of storytelling (Heath \& Heath, 2007; Lehrer, 2010; Salmon, 2008).

While discourse only activates the cerebral cortex (rational brain), stories activate the cortex by triggering the perceptive, motor and emotional systems in an integral way through mirror neurons (Ramachandran, 2011; Rizzolatti \& Sinigaglia, 2006); hence, their motivating potential.

The paradox is that, in the academic world, the informational competence of students is focussed almost exclusively on their ability to search for, analyse, select, filter, contrast, organize, synthesize, use and communicate information, while persuasive communication professionals avoid using information and focus on stories and storytelling. In short, the new generations of citizens leave the educational environment without specific preparation for dealing with communication strategies that are increasingly present in the environment in which they move.

\section{The inadequacy of the cognitive}

The polarization of the academic world towards the cognitive aspects could be justified by arguing that students live a very intense emotional relationship with the technologies outside the classroom and that the objective of the education system is to counterbalance this by incorporating the rational, reflective dimension. 
This seemingly reasonable argument crashes headlong with the more recent contributions of neuroscience in relation to brain functioning, especially from the point of view of the mental processes underlying decision-making.

Today it is known that the emotional brain is essential for the correct functioning of the rational brain: "Emotions are the foundation of everything we do, even reasoning" (Maturana \& Bloch, 1998: 137). "Certain aspects of the process of emotion and feeling are indispensable for rationality" (Damasio, 1996: 10). "The limbic system (the emotional brain) is the brain's power plant" (Carter, 2002: 54). Perhaps the most radical expression in this respect comes from Jonah Lehrer (2010): "Reason without emotion is impotent" (idem: 26). And even more emphatically: "If it weren't for our emotions, reason wouldn't exist at all" (Lehrer, 2010: 13).

The forcefulness of these quotes should lead university teachers to question whether the difficulties they encounter in obtaining rational attitudes and behaviours from students are not largely a consequence of their inability as educational professionals to elicit emotional responses from them.

\section{The inadequacy of critical thinking}

There is often criticism that the instrumental approach dominates the panorama of education technology. However, this happens because it is the most comfortable approach: Firstly because technology, being a material, specific and visible product, is easier to evaluate than an abstract and intangible process. Secondly, because its materiality becomes a result in itself: a classroom set up with screens and devices is a modern and innovative space per se. Thirdly, because the idea persists that technologies are neutral, and thus are subordinated to the use given to them, which puts them above any questioning, usually associated with resistance to change or little clarity about the specific advantages they offer beyond the initial novelty of their incorporation. As a recent article in The Economist (2017) notes: "education technology (edtech) has repeated the cycle of hype and flop, even as computers have reshaped almost every other part of life. One reason is the conservatism of teachers and their unions. But another is that the brain-stretching potential of edtech has remained unproven".

From this comfortable approach "the processes of innovation through ICTs that have been implemented in university institutions have tended to focus on the translation of materials and tools into digital formats. That is to say, most curricular materials have been digitised without transforming the foundations of the dominant educational paradigm" (Gómez, 2014: 51). In this regard, Steven Johnson (2010) believes that innovation can only occur in an environment that facilitates relationships between people and diverse materials that can be explored and recombined. The university system, like the school system, is usually rigid, based on the principles of repetition and vertical control, and against risk or error, concepts outlawed from academic vocabulary. The projects to incorporate technologies in education therefore prefer the product to the process, with the aim of efficiency based on the transmission of contents.

Finally, Neuroscience experts implicitly highlight the shortcomings of the academic world when they affirm that "consciousness can only be understood by studying the unconscious processes that make it possible" (LeDoux, 1999: 32). Screens are an 
excellent opportunity to access the unconscious, a prerequisite for in-depth understanding (Keysers, 2011; Mlodinow, 2013; Van Praet, 2012).

\section{Method}

As we explained in the introduction, the main objective of this article is to critically analyse the approach to educational technology in education studies in Spanish universities. We started with three research hypotheses:

H1: Educational technology in education studies in Spain focussed on the information field, and entertainment is barely present if not completely excluded.

H2: Educational technology in education studies in Spain is directed far more at the cognitive than the emotional.

H3: Educational technology in education studies in Spain relates critical sense to knowledge more than attitude.

To confirm or refute these hypotheses, we carried out a thematic content analysis (Andreu, 2002). Two types of documents were analysed. Firstly, 50 articles and communications published in the last 5 years in the academic reference indexes that focus on the use of technologies in the university education context. These documents had been compiled and analysed in an earlier research project that aimed to evaluate the scientific production on the use of technologies in the education field (Mateus, Aran-Ramspott \& Masanet, 2017). They include scientific articles and communications about experiences and research carried out in Spanish universities, based on self-reported initiatives such as innovations in the integration of educational technologies. To carry out this systematic review, the following inclusion criteria were used: range of years (2012-2016); publication in the chosen indexes (Web of Science, Scopus and Google Scholar); and inclusion in its metadata (titles, abstracts and keywords) of ed-tech related words. The result of this analysis was 50 items (42 of them belonging to scientific journals and the remaining eight to proceedings). Secondly, we analysed 194 teaching guides for education technology subjects taught in Spanish education faculties (pre-primary, primary, pedagogy and social education). These guides are part of a previous study that analysed media education in Spanish universities (Ferrés \& Masanet, 2015). Teaching guides for university subjects are the documents that specify the objectives, the skills the students need to acquire, the theoretical programme and practical activities, methodology, bibliography and teaching techniques. The teaching guides are based on the principles of the convergence process for the creation of a European Higher Education Area, which is governed by the Declaración de Bolonia (1999). Here we focus only on the teaching guides for education studies because it is compulsorily for these studies to include educational technology subjects, considering that the objective of these studies is to prepare teachers for their future educational work with children and adolescents, who need to be competent for life in a media environment.

These two types of documents are an appropriate sample for the first objective of the article, which is to identify the actions performed in the context of educational technology in Spanish universities. Despite these two informative products being different in terms of origin and objectives -one is institutional and the other one comes from the 
research field-, they are the only official documents available. On the other hand, if the results from these two informative products are similar it should confirm the validity of the hypothesis raised.

To carry out the analysis, we first identified a series of semantic fields and terms linked to these fields, updating those used in previous studies (Ferrés \& Masanet, 2015; Ferrés, Masanet \& Marta-Lazo, 2013) (see Table 1).

These semantic fields have been created following basic guidelines developed from neuroscience findings on the functioning of the human brain that demonstrate the need to work with emotions, entertainment and attitudes in an educational context, as discussed earlier.

Secondly, the word frequency in all the articles, communications and teaching guides was determined with the software for qualitative analysis NVivo Pro. Based on these frequencies and their distribution by semantic fields we studied each document individually to analyse and verify the context in which these terms were expressed. Thirdly, the results were presented quantitatively with word clouds. Finally, the analysis results of the documents were contrasted with some of the discoveries that neuroscience has made during the last decades in relation to decision-making processes. The critical analysis is based on three key areas: information, rationality and critical sense. In order to do so, we used the rhetorical figure of the paradox.

\section{Results}

\section{The paradox of information}

In 2006, with the appearance of the Organic Law of Education (LOE), digital competence became part of the prescriptive curriculum linked to the treatment of information. Digital literacy was structured from the outset around two central poles: the technological and the informational.

Already in 2001 the definition of digital literacy proposed by UNESCO referred to the set of skills, knowledge and attitudes that a person needs to be able to develop functionally within the Information Society. UNESCO followed experts who, at the end of the last century, expressed themselves along the same lines, demanding digital literacy "to enable students to understand and use information sources presented through computers" (Gilster, 1997: 6).

Table 1 Distribution of terms by semantic fields (We searched for all words in Spanish, English, Catalan and Galician, as well as all variations of gender and number and their respective conjugations)

\begin{tabular}{ll}
\hline Semantic Field & Terms linked to the Semantic Field \\
\hline Rational & $\begin{array}{l}\text { know, reason, reflection, knowledge, information, comprehension, understanding, } \\
\text { opinion, thought, analysis, concept } \\
\text { emotion, feeling, motivation, attitude, desire, pleasure, empathy, taste, unconscious, } \\
\text { subconscious } \\
\text { information, knowledge, concept, comprehension, understanding }\end{array}$ \\
Information / Knowledge & $\begin{array}{l}\text { entertainment, free-time, leisure, fun, storytelling, story, game, gamification, simulation } \\
\text { Entertainment }\end{array}$ \\
$\begin{array}{l}\text { Critical linked to } \\
\text { knowledge }\end{array}$ & $\begin{array}{l}\text { interpretation } \\
\text { Critical linked to attitude }\end{array}$ \\
\hline
\end{tabular}


The academic world has readily accepted technologies as support for the Information and Knowledge Society and as an opportunity to enhance the information competence of citizens.

In this reductionist polarization of technology to information, it is forgotten that in people's daily lives, entertainment and the relationships and interactions with others are as much or more important than the information. This is even more true for children and young people.

The academic world is comfortable with concepts like Information Society or Knowledge Society because they are part of its domain, its tradition:

Policy decision makers in many countries began [since 1990] adopting the rhetoric of the information society, the knowledge society, and twenty-first century skill requirements. The United Nations Educational, Scientific, and Cultural Organization (UNESCO, 1999) on "Task Force on Education for the Twenty-First Century," the European Union's project, i2010, on "A European Information Society for Growth and Employment" (i2010, 2007), and the "Okinawa Charter on the Global Information Society" of the G8 world leaders (G8, 2000) all reflect the movement at all levels of policy making (Anderson, 2008: 9)

In the same way, UNESCO's last world education report titled Rethinking Education: Towards a global common good? (UNESCO, 2015) states thatthe challenge becomes how to teach learners to make sense of the vast amount of information they encounter everyday, identify credible sources, assess the reliability and validity of what they read, question the authenticity and accuracy of information, connect this new knowledge with prior learning and discern its significance in relation to information they already understand (41).

But at the same time, feels uncomfortable with the phenomenon of entertainment because it considers it outside its interests, irrelevant in socialization processes and, although it does not explicitly confess this, because it does feel competent to deal with it.

In the 50 articles on technological innovation analysed there are 1468 references to terms belonging to the semantic field of information. In contrast, there are only 253 references to the semantic field of entertainment. Only 17 of the 50 articles (34.00\%) contain concepts related to entertainment, fun or leisure (a total of 49 references). These documents are linked to educational innovation, thus many of the educators intend to innovate by linking technology strictly to the informational. Terms related to stories and narrative (a total of 63 references) only appear in 12 of the 50 documents $(24.00 \%)$, which implies that $76.00 \%$ of the authors make no reference at all to storytelling. Finally, 28 of the 50 articles $(56.00 \%)$ contain concepts related to game, gamification and simulation (141 references). In this case the percentage is higher than the previous, but it is also important to highlight that 60 of the 141 references are included in just one document. Therefore, a single document incorporates $42.55 \%$ of these references.

In the 194 teaching guides of technology subjects in Spanish university education faculties there are 1817 references to terms linked to the semantic field of information, while there are only 189 references to terms linked to the semantic field of entertainment. Only 
20 of the 194 teaching guides (10.31\%) explicitly refer to the concepts of entertainment, fun or leisure (27 references), which means that $89.69 \%$ of the teachers who teach these subjects can be competent in the digital age without considering the dimension of entertainment.

The case of terms related to stories and narrative in the teaching guides follows a similar pattern to that of the articles and communications. There are only 102 references distributed in 42 of the 194 documents (21.65\%), implying that $78.35 \%$ of authors do not include any technology teaching guidelines that reference storytelling. Finally, the case of terms related to game, gamification and simulation is similar to the previous ones. There are only 60 references distributed in 40 documents $(20,62 \%)$.

The analysis of these documents shows that concepts such as gaming, gamification, simulation or virtual reality that connect with the sphere of the emotional and entertainment and that could contribute to enhance learning appear rarely, which agrees with the results of other studies around the Spanish university in which it is clear that the incorporation of these concepts is still in the minority and has significant gaps (Llorens-Largo et al., 2015; Peñalba, 2017).

Figure 1 illustrates the disproportion between the references to terms from the fields of information and entertainment. As it can be seen, references to entertainment are practically non-existent, given the low number found in the entire set of documents. In short, we speak of the informational paradox not only because this disproportion in academic attention between information and entertainment conflicts with people's daily practices, and particularly those of children and young people, but also because of the relevance of persuasive and emotional strategies such storytelling presented at the beginning.

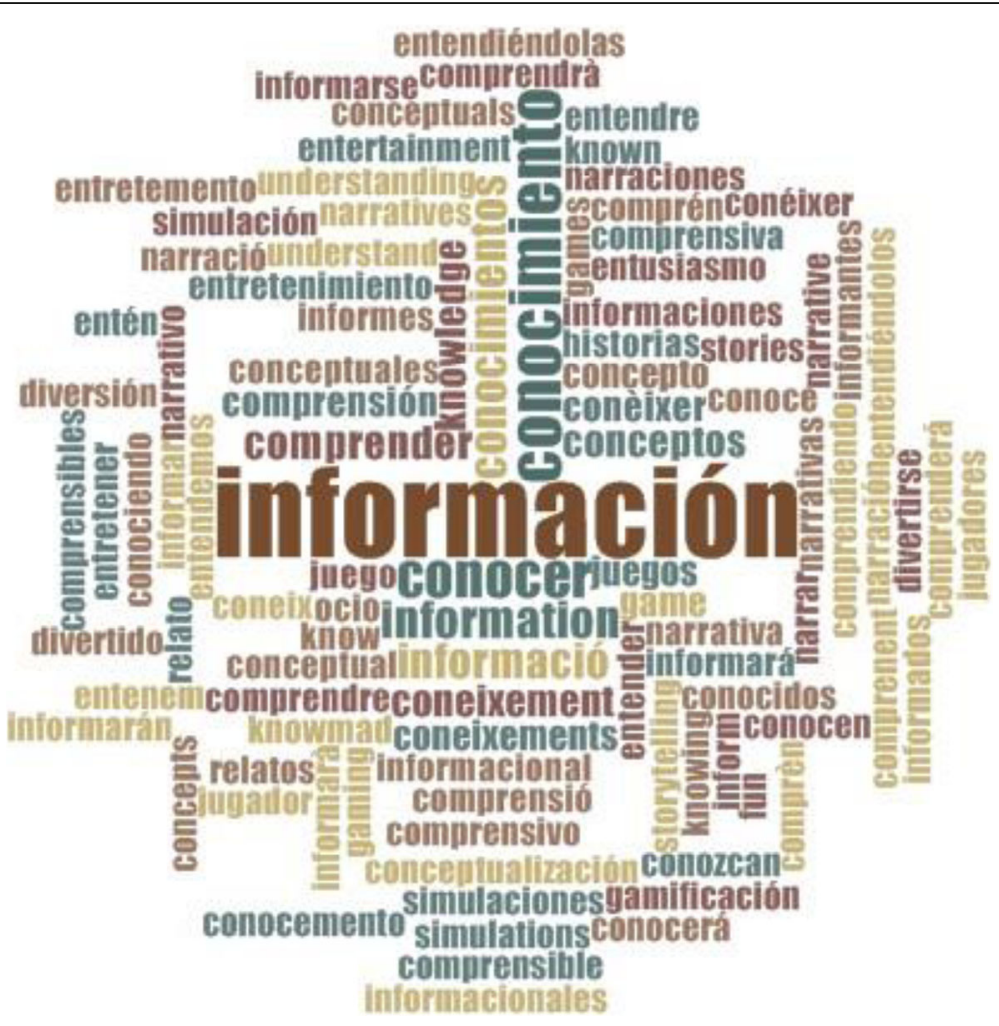

Fig. 1 Cloud of informational and entertainment fields in articles and guides. Source: Own Creation 


\section{The paradox of the cognitive}

In both the analysis of the 50 documents on educational innovation using technologies and in the 194 teaching guides of the technology-related subjects in Spanish education faculties, we discover a polarization towards the cognitive and rational, and a significant, if not total, marginalization of the emotional dimension.

In the 50 documents on educational innovation there are 2649 references to terms linked to the cognitive-rational semantic field and only 245 references to terms linked to the semantic field of emotion. There are only six explicit references to emotions, which means that 45 of the 50 documents (90\%) do not make a single direct reference to emotions. It would seem that the aim is to innovate while totally marginalizing this dimension, intentionally or not.

In the entire set of articles and communications there are 80 references to motivation, but there are 18 documents (36\%) that do not contain a single reference to this concept. Bearing in mind that these are texts focused on university educational innovation through technology, this lack is alarming, since the students' motivations are a key aspect for learning.

In the 194 university teaching guides analysed, there are 6068 references to terms related to the cognitive-rational semantic field and only 396 references to terms related to the semantic field of emotion. There are only 78 direct references to emotions, and these are distributed among 41 guides (21.13\%). Therefore, there are 153 teaching guides $(78.87 \%)$ in which there is not a single reference to concepts related to emotions.

Regarding motivation, in the set of guides there are 33 references to motivation, but there are 169 documents (87.11\%) that do not make a single reference to this concept. Being teaching guides for technology subjects, this absence is worrying, since almost $90 \%$ of the guides do not make any reference to the students' motivations, a key aspect in the educational process.

Figure 2 confirms that the cognitive-rational field goes far beyond the emotional in the number of mentions. As the word cloud shows, the terms from the semantic field of emotion are barely visible.

\section{The paradox of criticism}

A further step in our research was aimed at detecting which conception of critical sense underlies the documents analysed. To achieve this, we analysed contextually with which noun the adjective "critical" was associated in each case. We were primarily interested in detecting whether the critical sense was related to the cognitive or the emotional. In other words, with thought or attitude.

In some cases the associated terms are ambiguous from this point of view. For example, when we talk about critical capacity, critical perspective, critical sense, critical awareness, and critical factors, among others. Or simply when critical is used as a noun: criticism, critics. In other cases the term is associated with concepts that are clearly cognitive: critical analysis, critical view, critical reading, critical understanding, critical reflection, critical evaluation, critical look, critical approach, and, above all, critical thinking. Finally, some associations can be related to the emotional: critical attitude, critical commitment, critical posture, critical use. 


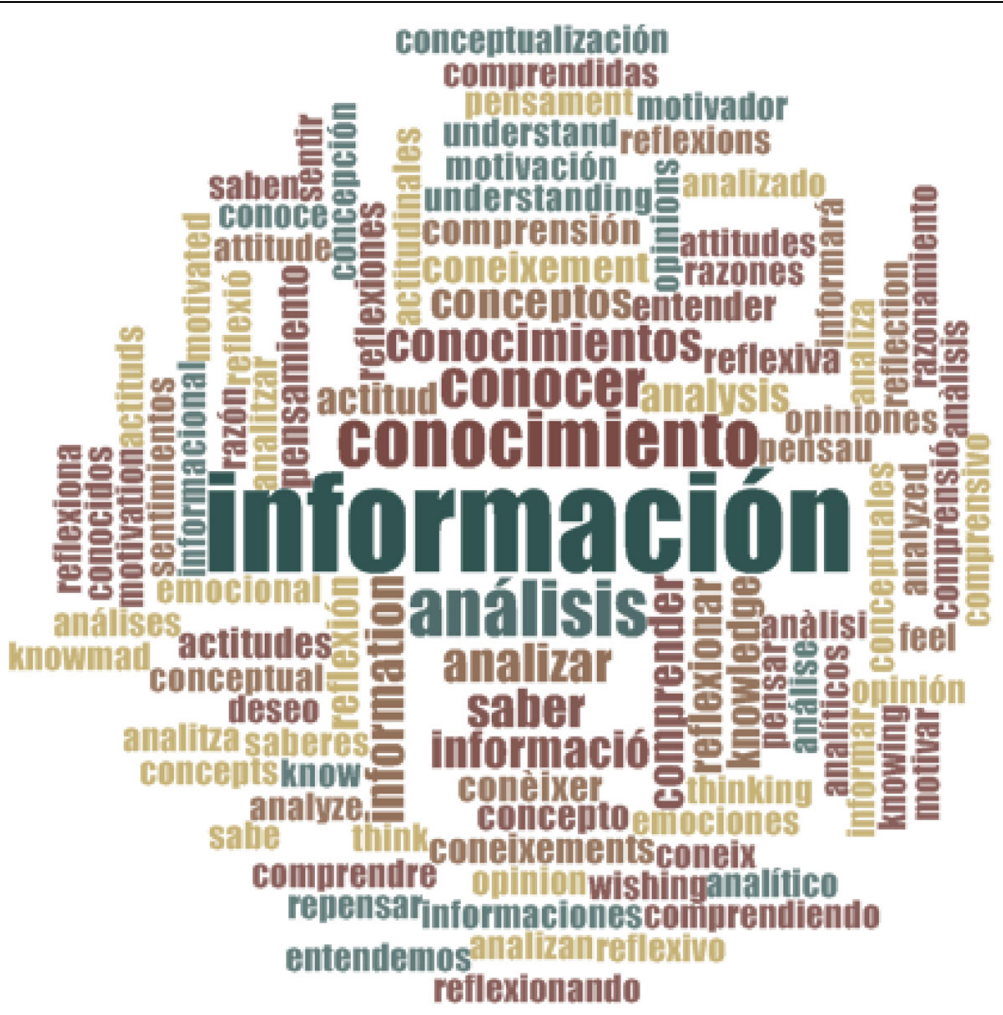

Fig. 2 Cloud of cognitive-rational and emotional fields in articles and guides. Source: Own Creation

Of the 50 documents dealing with education technology innovation only 23 include the concept of critical (46\%), and in these there are only 55 references to critical. Of these 55 references, most are associated with terms from the cognitive field and very few with the emotional field. For example, there is much talk about critical thinking or analysis (8 references) while there is not a single reference to "critical attitude".

On the other hand, in 52 of the 194 teaching guides (26.80\%) there is no reference to critical. And in the 142 guides (73.20\%) where references do appear (a total of 613 references) these are polarized towards the cognitive field. If we combine the three most-used terms of the cognitive field (critical analysis, critical incorporation and critical vision) we obtain a total of 170 references. However, combining the three mostused terms in the emotional field (critical attitude, critical posture and critical use) we only obtain 37 references.

In Fig. 3 we can see the disproportion between the terms associated with critical. As in the previous clouds, we are working with articles, communications and teaching guides.

This lack is particularly serious in the light of statements by neuroscience experts: "Emotions create a fury of activity dedicated to a single goal. Thoughts, unless they activate the emotional mechanisms, do not do this" (LeDoux, 1999: 337).

Thoughts and knowledge do not motivate if they do not turn into feelings. Knowing that you are going to die 1 day does not impel you to review your life and your value system. You only do this when you have an accident or when a loved one dies; that is, when knowledge is accompanied by feelings. 


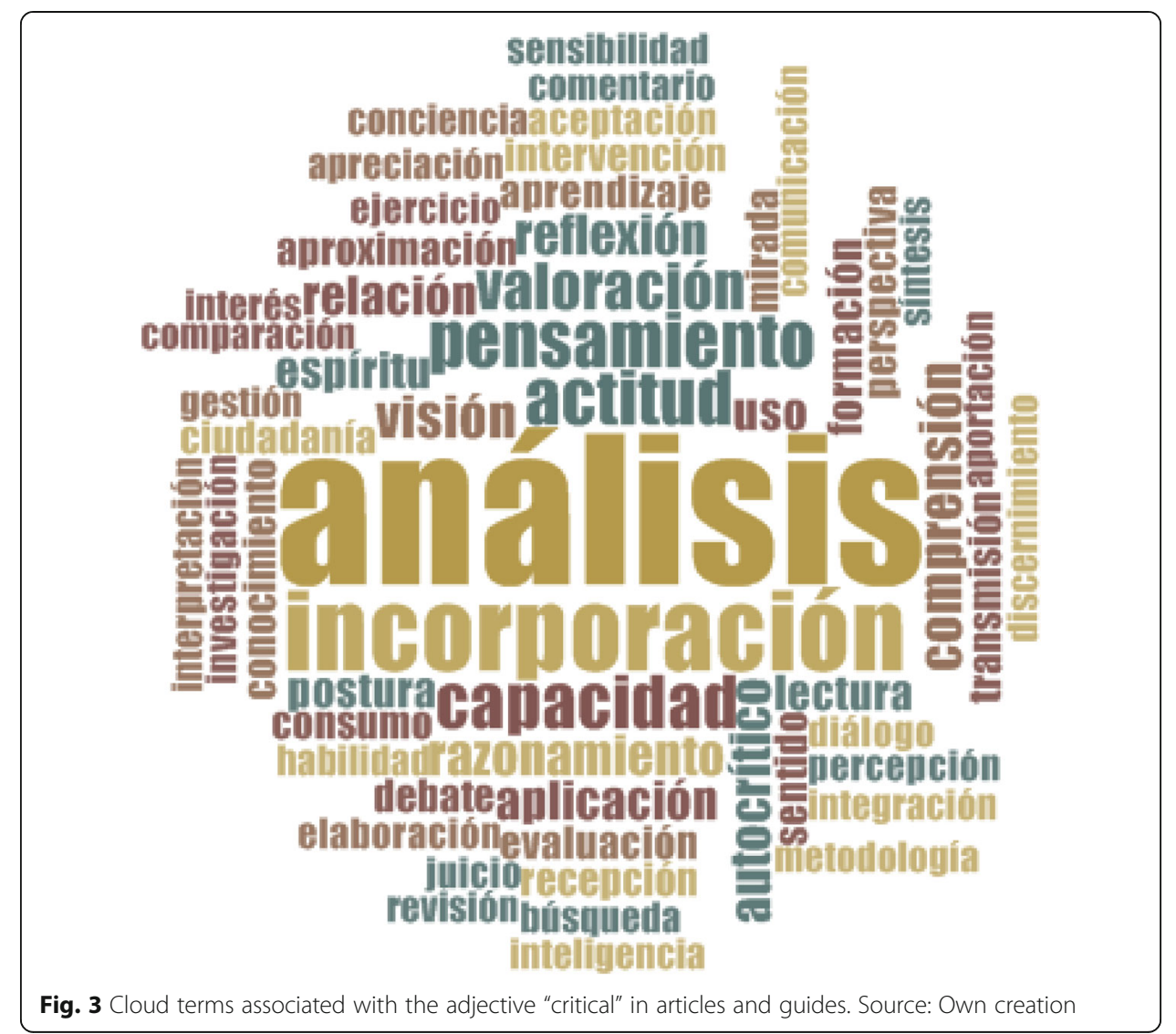

Neurobiologist Donald Calne states that "the essential difference between reason and emotion is that while emotion leads to action, reason leads to drawing conclusions" (quoted by Roberts, 2005: 42). If we intend to achieve the transformation of the students, e critical thinking, critical understanding, critical reading or critical analysis should be just a step. The main objective of education should be a critical attitude, understanding attitude as a drive, an impulse, a willingness to act.

Of course, there can be no critical attitude without critical thinking, but critical thinking is insufficient if education is intended to enhance the personal autonomy and social commitment of citizens.

As already stated, in the set of 50 documents on educational innovation the concept of critical is referenced 55 times; however, in these references, self-criticism is referred to only twice. Similarly, in the set of 194 teaching guides the term critical appears 613 times, and only 16 of these refer to self-criticism.

These data reveal another significant lack in Spanish university education. If criticism is almost always only heterocritical (we must learn to criticize messages, products, information, and news, among others), it is because knowledge does not include selfknowledge. No account is taken of the great challenge already proposed by the Ancient Greek aphorism of the Delphic oracle considered the principle of wisdom: "know thyself." In the Information and Knowledge Society, no attention is given to information and knowledge about oneself.

Every effort is made to take advantage of the screens as windows, as an opportunity to access the external reality, to accumulate information and knowledge about the 
world, and hardly any effort is made to take advantage of the possibilities of the screens as mirrors, as an opportunity to find yourself, and especially as an opportunity to access your own unconscious, the dark side of yourself, the most latent contradictions.

\section{Discussion}

Two conclusions emerge from the considerations made so far: it is necessary to include new contents in the educational treatment of technologies, and it is necessary to change the point of view from which contents are treated.

Concerning the new contents, as we indicated at the beginning of the article, the development of personal autonomy and social commitment requires, in addition to the mastery of technology, the knowledge and capacity to manage the mental processes of the people who use these technologies. It is not possible to use the technologies to their full potential without a deep knowledge of the mechanisms that govern the minds of those who interact with them.

The knowledge and capacity to manage emotions in their cognitive dimension and from their motivating potential (Damasio, 1996, 2005; LeDoux, 1999) are essential for ensuring both the effectiveness of educational communication and facilitating understanding of the socializing and educational force that screens have, even when this is not their objective or their intention (Ferrés, 2014; Bueno, 2017; Mora, 2013).

The knowledge and capacity to manage mirror neurons, one of the most transcendental discoveries of neuroscience during the last decades (Keysers, 2011; Ramachandran, 2011; Rizzolatti \& Sinigaglia, 2006), are essential for understanding the processes of teaching by imitation or models, the processes of empathy and the socialization strategies of stories, through identification and projection mechanisms.

Still in relation to the incorporation of new content, together with the actual information, we need to pay attention to the field of entertainment and particularly to storytelling, both so that the students understand how they are socialized through media stories and so that teachers can take full advantage of educational communication by incorporating these resources.

Concerning the need to change the point of view, in education it is necessary to take a step towards emphasizing attitudes more than knowledge. In other words, we should approach thoughts and knowledge only as a preliminary step towards attitudes. There is often talk of the need to turn information into knowledge. In fact, it is necessary to go one step further and add the requirement of turning knowledge into attitudes.

We conclude by saying that the reflections and contributions that have been made here are largely the result of the research that the authors of the article have carried out in recent years in the media education field (Mateus, Aran-Ramspott \& Masanet, 2017; Ferrés \& Masanet, 2015; Ferrés, Masanet \& Marta-Lazo, 2013.; Ferrés \& Masanet, 2017).

\section{Limitations and further research}

In this article, we have focused only on teaching guides and published work in the last years corresponding to education studies, therefore its results cannot be generalized to all higher education. Perhaps the polarization in the cognitive, the rational and the informative is not exclusive of the subjects or academic fields linked to technology exclusively, but a tendency of education in general. It would have to be confirmed in 
later investigations. Likewise, future work must integrate qualitative methodologies that allow a better understanding of the subjective view of the teachers who use educational technologies.

Acknowledgements

Not applicable.

Funding

This work was funded by the $\mathrm{R}+\mathrm{D}+\mathrm{i}$ project "Media literacy in the emerging digital media in university environments" (EDU2015-64015-C3-2-R) of the Ministry of Economy and Competitiveness of Spain.

Availability of data and materials

Datasheets available upon request.

\section{Authors' contributions}

All authors read and approved the final manuscript.

\section{Authors' information}

Joan Ferrés holds a Ph.D in Information Sciences (Autonomous University of Barcelona), a Degree in Information Sciences (Autonomous University of Barcelona) and a Degree of Teacher in Primary Education (Barcelona University). $\mathrm{He}$ is Associate Professor (tenure) at the Department of Communication of the University Pompeu Fabra (Barcelona, Spain). Researcher specialized in media literacy, communication and education and emotional competence. He has been the PI of different projects related with media literacy as Undergraduate teaching faced with the audiovisual communication competence in a digital environment and Evaluation of the media competence of Spanish citizenship. Maria-Jose Masanet holds a Ph.D. in Social Communication (Universitat Pompeu Fabra, 2015), a Degree in Audiovisual Communication (Universitat Pompeu Fabra, 2008), a MA in Social Communication ((Universitat Pompeu Fabra, 2009) and a MA in Secondary Education (Universitat Politècnica de Catalunya, 2011). She is researcher at the Pompeu Fabra University. Her main research lines are related with media literacy, adolescence and youth, series, gender and the representation of sexuality and love relationships in the media. She has published the book La educación Mediática en la Universidad Española (Gedisa, 2015) with Dr. Joan Ferrés. She has been visiting researcher at the Loughborough University (2013), at the Universidad Central de Venezuela (2014), at the Université Sorbonne Nouvelle Paris 3 (2015) and at the Centre de Liaison de l'Enseignement et des Médias d'Information (2015) and at the Ghent University (2016). Julio-César Mateus holds a Master in Advanced Studies in Social Communication (Universitat Pompeu Fabra), a Master's Degree in Communication and Education (Universitat Autònoma de Barcelona) and a B.A. in Communication (University of Lima). He studies the PhD Program in Communication (UPF). As a fellow of the Department of Communication, he collaborates in research projects and develops his doctoral thesis on media education in teacher training. He has taught in the degree of Communication of the University of Lima, the Master in ICT and Education of the Pontificia Universidad Católica and in the Department of Social and Political Sciences of the University of the Pacific, in Peru. He is guest professor of the Master in Communication at Casagrande University, in Ecuador.

\section{Ethics approval and consent to participate}

Not applicable.

\section{Consent for publication}

Not applicable.

\section{Competing interests}

The authors declare that they have no competing interests.

\section{Publisher's Note}

Springer Nature remains neutral with regard to jurisdictional claims in published maps and institutional affiliations.

Received: 3 August 2017 Accepted: 20 February 2018

Published online: 04 April 2018

\section{References}

Adams Becker, S., Cummins, M., Davis, A., Freeman, A., Hall Giesinger, C., \& Bueno, D. (2017). Neurociència per a educadors. Barcelona: Associació de Mestres Rosa Sensat.

AECT Definition and Terminology Committee (2008). Definition. In A. Januszewski, \& M. Molenda (Eds.), Educational technology: A definition with commentary. New York: Lawrence Erlbaum.

Anderson, R. E. (2008). Implications of the information and knowledge society for education. In J. Voogt, \& G. Knezek (Eds.), International handbook of information technology in primary and secondary education, (pp. 522). Boston: Springer.

Andreu, J. (2002). Las técnicas de Análisis de Contenido: Una revisión actualizada, Centro de Estudios Andaluces. Retrieved from: http://public.centrodeestudiosandaluces.es/pdfs/S200103.pdf. Accessed 20 Feb 2018

Bueno, D. (2017). Neurociència per a educadors. Barcelona: Associació de Mestres Rosa Sensat.

Carter, R. (2002). El nuevo mapa del cerebro. Barcelona: RBA Ediciones de Librerías, Col. Integral.

Casas, M., \& Stojanovic, L. (2013). Innovation in Ibero-American Universities. Universities and Knowledge Society Journal (RUSC), 10(1), 240-253. https://doi.org/10.7238/rusc.v10i1.1345. 
Damasio, A. (1996). El error de Descartes. Barcelona: Crítica.

Damasio, A. (2005). En busca de Spinoza. Neurobiología de la emoción y los sentimientos. Barcelona: Crítica.

Declaración de Bolonia (1999). Declaración conjunta de Ministros Europeos de Educación. Retrieved from: https://www. eurashe.eu/library/modernising-phe/Bologna_1999_Bologna-Declaration.pdf. Accessed 20 Feb 2018

Englund, C., Olofsson, A. D., \& Price, L. (2016). Teaching with technology in higher education: Understanding conceptual change and development in practice. Higher Education Research \& Development, 36(1), 73-87. https:// doi.org/10.1080/07294360.2016.1171300.

Ferrés, J. (2014). Las pantallas y el cerebro emocional. Barcelona: Gedisa.

Ferrés, J., \& Masanet, M-J. (eds.) (2015). La educación mediática en la universidad española. Barcelona: Gedisa.

Ferrés, J., \& Masanet, M.-J. (2017). Communication Efficiency in Education: Increasing Emotions and Storytelling. Comunicar, 25(52), 51-60. https://doi.org/10.3916/C52-2017-05.

Ferrés, J., Masanet, M-J., \& Marta-Lazo, C. (2013). Neurociencia y educación mediática: carencias en el caso español. Historia y Comunicación Social, 18(3), 129-144

Gilster, P. (1997). Digital Literacy. New York: Wiley.

Gómez, F. (2014). Educational innovation through ICTs in the university setting. What do students think of these practices? Revista de Universidad y Sociedad del Conocimiento (RUSC), 11(1), 49-60. https://doi.org/10.7238/rusc.v1111.1657.

Gómez, J. (Ed.) (2016). UNIVERSITIC 2016. Análisis de las TIC en las Universidades Españolas. Madrid: Crue Universidades Españolas.

Heath, C., \& Heath, D. (2007). Made to stick: Why some ideas survive and others die. New York: Random House.

Johnson, S. (2010). Where good ideas come from: The natural history of innovation. New York: Penguin.

Keysers, C. (2011). The empathic brain. How the discovery of mirror neurons changes our understanding of human nature. Amsterdam: Social Brain Press.

LeDoux, J. (1999). El cerebro emocional. Barcelona: Ariel/Planeta.

Lehrer, J. (2010). How we decide. Boston: Houghton Mifflin Harcourt.

Llorens-Largo, F., Gallego-Durán, F. J., Villagrá-Arnedo, C. J., Compañ-Rosique, P., Satorre-Cuerda, R., \& MolinaCarmona, R. (2015). Lecciones aprendidas gamificando cuando aún no se llamaba gamificación, (pp. 214-219). Madrid: III Congreso Internacional sobre Aprendizaje, Innovación y Competitividad Recuperado de: https:/I goo.gl/NZR7UA (07/04/17)

Mateus, J. C., Aran-Ramspott, S., \& Masanet, M-J. (2017). Revisión de la literatura sobre dispositivos móviles en la universidad española. RIED. Revista Iberoamericana de Educación a Distancia, 20(2), 49-72. https://doi.org/10.5944/ ried.20.2.17710

Maturana, H., \& Bloch, S. (1998). Biología del Emocionar y Alba Emoting. Respiración y emoción. Santiago de Chile: Dolmen. Mlodinow, L. (2013). Subliminal: cómo tu inconsciente gobierna tu comportamiento. Barcelona: Crítica.

Mora, F. (2013). Neuroeducación. Solo se aprende aquello que se ama. Madrid: Alianza.

Peñalba, S. (2017). Los profesores universitarios españoles ante la gamificación. Una perspectiva educomunicativa. Master Thesis. Huelva: Universidad Internacional de Andalucía y Universidad de Huelva.

Ramachandran, V. S. (2011). The tell-tale brain. New York: W.W. Norton \& Company.

Rizzolatti, G., \& Sinigaglia, C. (2006). Las neuronas espejo. Los mecanismos de la empatía emocional. Barcelona: Paidós.

Roberts, K. (2005). Lovemarks. El futuro más allá de las marcas. Barcelona: Urano.

Salmon, C. (2008). Storytelling. La máquina de fabricar historias y formatear las mentes. Barcelona: Península.

Sevillano-García, M. L., \& Vázquez-Cano, E. (2015). The impact of digital mobile devices in higher education. Educational Technology \& Society, 18(1), 106-118.

Sutton, K., \& DeSantis, J. (2016). Beyond change blindness: Embracing the technology revolution in higher education. Innovations in Education and Teaching International, 54(3), 1-6. https://doi.org/10.1080/14703297.2016.1174592.

The Economist. (2017). Together, technology and teachers can revamp schools. The Economist. Retrieved from https://www. economist.com/news/leaders/21725313-how-science-learning-can-get-best-out-edtech-together-technology-andteachers-can. Accessed 20 Feb 2018

UNESCO (1999). Task force on education for the twenty-first century. Retrieved from: http://www.unhas.ac.id/rhiza/ arsip/pembelajaran/unesco.html (20/02/2018).

UNESCO (2015). Rethinking education: Towards a global common good? Paris: UNESCO Retrieved from http://unesdoc. unesco.org/images/0023/002325/232555e.pdf (26/01/2018).

Van Praet, D. (2012). Unconscious branding. How neuroscience can empower (and inspire) marketing. New York: Palgrave MacMillan

Vázquez-Cano, E. (2015). El reto de la formación docente para el desarrollo de una metodología ubicua en la Educación Superior. Perspectiva Educacional, 54(1), 149-162. https://doi.org/10.4151/07189729-Vol.54-Iss.1-Art.236. 